\title{
Controle social: análise da relação entre o Estado e - lumpemproletariado da Cracolândia de São Paulo durante o lulismo
}

\author{
Marcela Maria Carvalho PONTES(1)
}

Recebido: 28 jan 2019 Aceito: 10 fev 2019

Autor de correspondência: marcelacpontes@hotmail.com Conflito de interesses: Os autores declaram não haver nenhum interesse profissional ou pessoal que possa gerar conflito de interesses em relação a este manuscrito.

\footnotetext{
${ }^{(1)}$ Escola de Enfermagem, Universidade de São Paulo - USP, São Paulo, SP, Brasil.
}

\section{Resumo}

Esse estudo realizou análise documental das políticas públicas de saúde implementadas no espaço social da Cracolândia de São Paulo durante o período no qual o Governo Federal esteve sob o comando do Partido dos Trabalhadores PT, governos de Luiz Inácio Lula da Silva e Dilma Rousseff (2003-2016). O objeto pesquisado é o controle social de Estado sobre a classe lumpemproletarizada da Cracolândia de São Paulo. Em "Três Ensaios Acerca das Considerações Teóricas" um capítulo "De braços abertos: lumpemproletariado na rede neoliberal de controle" - que tem por finalidade buscar a relação entre o Estado brasileiro e a classe lumpemproletarizada, historicamente e de maneira totalizante, deu início à justificativa para a hipótese de estudo. Desse modo, "Superestrutura e Lumpemproletariado", um subtítulo dessas Considerações, realiza abordagem teórica dos conceitos de superestrutura e lumpemproletariado, assim como do objeto de pesquisa: o controle social durante o período de acumulação neoliberal. Panorama histórico está dividido em três subdivisões: o primeiro, "Respostas Brasileiras ao Lumpemproletariado", retrata através de abordagem histórica algumas das relações entre o Estado brasileiro e o lumpemproletariado, das formas de controle social arcaicas às modernas aplicadas pelo Estado brasileiro historicamente. Em "Estado e Cracolândia" e "Capital Imobiliário e Cracolândia" estão reportadas algumas das relações entre Estado, capital e os sujeitos de pesquisa. "Fetichismo: droga como mercadoria" é a terceira parte do capítulo 3 e realiza discussão acerca das relações ocultadas ou fetichizada pela mercadoria droga ilícita. Após a composição histórica e social da relação entre o "Estado brasileiro e o Lumpemproletariado" trazida em Considerações Teóricas, esse estudo tem por objetivo realizar análise sobre o tipo de composição/forma das políticas públicas aplicadas ao espaço social da Cracolândia de São Paulo sob a luz da noção de Controle Social, dado que esse conceito se insere para o materialismo histórico e dialético a partir do conceito de Superestrutura da sociedade capitalista. Sendo assim, para o pensamento marxista a categoria de superestrutura remete à parte da estrutura social em que estão compreendidas as relações políticas e ideológicas de uma sociedade, nesse caso, capitalista no período de acumulação neoliberal. A superestrutura é constituída pelas instituições civis e de Estado que organizam as estratégias e dinâmicas de funcionamento do cotidiano, delineando, a partir de suas ações, a cultura e as 
formas de viver das pessoas e classes sociais. E foi a partir dessa categoria estudo que se compreendeu a noção de Controle Social enquanto objeto de pesquisa. Metodologia escolhida orienta o referencial teórico-metodológico de pesquisa e o material de análise. A partir da análise documental dos materiais de Estado peças legislativas, portarias, decretos, cadernos e manuais ministeriais e de secretarias públicas -, além de documentos de mídia impressa e materiais acadêmicos balizadores das práticas de gestão pública, buscar-se a inter-relação entre o Estado e a classe social lumpemproletarizada. O delineamento do objeto de pesquisa foi realizado a partir de análise dialética do discurso legislativo e demais documentos seguindo a orientação de três pontos de apoio: o escrito, subscrito e sobrescrito. $O$ escrito refere-se a análise literal do texto escrito: suas informações e dados concretos. O subscrito refere-se a análise do significado dos escritos legais ou documentais, ou seja, sua base ideológica - principalmente o seu carácter socialdemocrata ou neoliberal - para tanto, utilizou-se de dois conceitos chave: ressignificação e novilíngua. O sobrescrito tem por objetivo relacionar as análises do escrito e subscrito dentro de uma conjuntura políticoeconômica definida, trata-se de uma análise de conjuntura sobre o período que deu origem às políticas públicas selecionadas para esse estudo: o Lulismo. Assim, a "Análise do objeto em lulopetismo: militarização e capilarização da sociedade civil" (um capítulo dessa pesquisa) representa a análise dos documentos selecionados a partir do conteúdo ideológico e da produção e planejamento das políticas públicas direcionadas à Cracolândia de São Paulo, a incluir o programa "Crack, É Possível Vencer", demonstrando que essas se orientam conforme as condicionalidades das instituições financeiras internacionais, portanto, possuem caráter neoliberal. Considerações Finais: finaliza o trajeto de pesquisa demonstrando que as formas de controle social sob a classe social apartada da terra e jamais absorvida pelo trabalho produtivo apresenta aspectos das formas arcaicas misturadas aos processos modernizadores, entre instituições totais e políticas de manutenção da reprodução social da classe lumpemproletariada. E que o período estudado, o lulopetismo, contribuiu para o processo de consolidação da reordenação superestrutural iniciada no Brasil na década de 1990 com o período Collor - o neoliberalismo. A lógica operacionalizada foi a construção de redes neoliberais (de forte imbricação público-privada), articuladas ministerialmente ou através das secretarias e a partir do orçamento público destinado às políticas focais, provocando inchaço da burocracia civil e com isso, a sua capilarização ideológica de classe e um projeto de controle social militarizado - nacional e localmente projetado para espaços de uso problemático de drogas ilícitas. Por fim, foi possível afirmar que houve capilarização (ideológica) da sociedade civil e aumento da militarização como mecanismo de controle da população lumpemproletariada

Descritores: Política Pública; Controle Social Formal; Drogas Ilícitas. 